This is the Accepted Version of 'How is the Rule of Law a Limit on Power?' Studies in Christian Ethics Vol. 29 Bo. 1 34-50, 2016 published by Sage. Please refer to the published version when citing: http://sce.sagepub.com/content/29/1/34

Accepted Version downloaded from SOAS Research Online:

http://eprints.soas.ac.uk/22491/

\title{
How is the Rule of Law a Limit on Power?
}

\author{
David McIlroy ${ }^{*}$
}

\begin{abstract}
KEY WORDS: RULE OF LAW, FULLER, AUGUSTINE, LAW IN THE CHARACTER OF GOD, NATURAL LAW
\end{abstract}

\begin{abstract}
A commitment to the rule of law is a commitment to the governance of a society through the use of general or generalizable rules which are binding on both the subjects and the rulers. By giving due notice of the rules and of any changes to them, those who are subject to the law are protected from violence and enabled to act as agents. This is the essential contribution the rule of law makes to important human goods including freedom. Such an understanding of the rule of law illuminates why the law-like character of God and the revelation of God's law make human free will meaningful and a relationship of love between God and human beings possible. A commitment to the rule of law also means that those exercising power have to offer justifications to explain why the rules are binding, which opens up space for debate about whether the rules are just.
\end{abstract}

\footnotetext{
* I am grateful to Julian Rivers for discussion of the ideas in this paper. The errors remain my sole responsibility.
} 


\section{Introduction}

I want to take you today into a strange land, into the land of legal philosophy. It is a strange land because debates within legal philosophy have become unhealthily isolated from a broad or long-term understanding of intellectual history. If Carl Schmitt was even half-right about political theory being a secular reflection of political theology, ${ }^{1}$ then one would expect theological insights to enrich and illuminate a debate within legal philosophy regarding the rule of law. A more surprising outcome of our journey is that, I hope, we will find insights on our travels which illuminate our understanding of God.

The traditional Christian view of natural law sees human law-making and judging as specifications and clarifications of natural law and divine law, both of which have their origins in God. This view of law was regarded by the legal positivists as both muddle-headed and dangerous. It was muddle-headed because it confused law as it is with law as it ought to be. ${ }^{2}$ It was dangerous because it created a presumption that laws were good and ought to be obeyed. The result was that in practice, despite the insistence of natural law theorists that an unjust law ought not to be obeyed, it bred an unhealthy deference to authority.

In the late nineteenth and early twentieth century, the legal positivists dominated the field of legal philosophy: it became axiomatic that law was just a tool, which could be wielded for evil purposes just as easily as it could be used in the pursuit of good ends.

Then, in the middle of the twentieth century, Lon L. Fuller said that there was an intrinsic discipline to making law and that this discipline amounted to a 'procedural natural law', ${ }^{3}$ though he insisted that it had 'nothing to do with

\footnotetext{
${ }^{1}$ C. Schmitt, tr. George Schwab, Political Theology. Four Chapters on the Concept of Sovereignty (London: MIT Press, 1985).

${ }^{2}$ This was the fundamental criticism made by John Austin, who tried to combine divine command theory, utilitarianism and legal positivism in The Province of Jurisprudence Determined, (London, 1832).

${ }^{3}$ Lon L. Fuller, The Morality of Law (New Haven: Yale University Press, revd. edn. 1969), pp. 96-97.
} 
any "brooding omnipresence in the skies"' and that it was "entirely terrestrial in origin and application'.

Fuller 'was concerned to show that even modern law - which is highly open to diverse contents and political programmes - serves a necessary minimal moral value. ${ }^{4}$ Fuller's claim was that in order to govern by law, there were at least eight matters to be considered:

(1) rules should be general or generalizable, ${ }^{5}$

(2) rules must be publicised,

(3) rules must not be retroactive,

(4) rules must be understandable,

(5) rules must not be contradictory,

(6) rules must not require the impossible,

(7) rules must not be changed so frequently that 'the subject cannot orient cannot orient his action by them', and

(8) there must be 'congruence between the rules as announced and their actual administration' 6

What Fuller identified as a set of procedures for law-making are better described as a set of formal requirements for law; they are practices which give law the distinctive form that it takes as a method of social organisation.

The legal positivists retorted that Fuller had mistaken effectiveness for goodness; that the discipline of law-making did not mean that law was inherently more suited for good purposes than for evil ones, all that he had done was to identify what you have to do if you want law to work for you as a tool. $^{7}$ Despite accepting that "many of the more common manifestations of power run foul of the rule of law", "Joseph Raz famously argued that [the rule of law is] only instrumentally valuable, making law "good" in the same way

\footnotetext{
${ }^{4}$ Rivers, 'The Rule of Law as Civic Virtue', in R. Heimburger ed. The Modern State and the Kingdom of God (Oxford: Las Casas Institute, 2012), pp. 1-8 at p.2.

${ }^{5}$ Legislation characteristically takes the form of general rules; case-law characteristically takes the form of generalizable rules.

${ }^{6}$ Fuller, The Morality of Law, p. 39.

${ }^{7}$ H.L.A. Hart, the greatest legal positivist of the twentieth century, opposed Fuller's position at Hart, The Concept of Law (Oxford: Clarendon, $2^{\text {nd }}$ edn, 1994), p. 207. Recent scholarship has, however, demonstrated that although Hart purported to disagree with Fuller, on some occasions he appears to concede Fuller's point that the rule of law has a moral value whilst at other times he maintains his denial: J. Waldron, 'Positivism and Legality: Hart's Equivocal Response to Fuller', New York University Law Review 83 (2008), pp. 1135-1169.

${ }^{8} \mathrm{~J}$. Raz, The Authority of Law: Essays on Law and Morality (Oxford: Clarendon, $2^{\text {nd }}$ edn, 2009), p.219.
} 
that a sharp knife is good, in other words, fit for purpose. ${ }^{9}$ In Raz's own case this assessment of the rule of law as neutral was qualified beyond the point of equivocation because Raz accepted that "the rule of law is an inherent virtue of law", and whilst "not a moral virtue of such", the benefits of conformity to the rule of law in restricting "many of the more common manifestations of arbitrary power" meant that "the rule of law ... is virtually always of great moral value." 10

The battle has raged on into the next generation of legal philosophers, dividing the law faculty at Cambridge. On the legal positivist side, Matthew Kramer has argued that an evil regime could successfully pretend to be governing in accordance with the rule of law whilst still perpetrating many serious forms of evil. Even more strongly than Raz, Kramer has asserted that the rule of law is a purely instrumental value, as serviceable for evil as for good. ${ }^{11}$ Central to Kramer's thesis is the idea that the officials in a wicked regime could have sufficient prudential, i.e. self-regarding, reasons for complying with the rule of law in pursuit of their iniquitous ends. ${ }^{12}$

Taking up Fuller's baton, Nigel Simmonds disagrees, contending instead that the rule of law is an inherently moral idea. ${ }^{13}$ Although some serious forms of evil could be perpetrated in a society which is governed by the rule of law, other types of evil are inhibited by the rule of law and that makes the rule of law valuable as a moral ideal in its own right. Simmonds is one of a number of contemporary legal philosophers who argue that there is, inherent to law as a social institution, a moral virtue called 'legality' which is distinct from the virtue of justice which Christian natural law theory regarded as the essence of law.

\footnotetext{
${ }^{9}$ Rivers, 'The Rule of Law as Civic Virtue', p.2; referring to the argument of Raz, The Authority of Law, p.226.

${ }^{10}$ Raz, The Authority of Law, p.226.

${ }^{11}$ M. Kramer 'On the Moral Status of the Rule of Law', Cambridge Law Journal 63 (2004), pp. 65-97.

${ }^{12}$ Kramer, 'On the Moral Status of the Rule of Law', pp. 66-77. Kramer's claim is not that wicked legal officials are in fact driven to comply with the rule of law by purely prudential concerns, merely that is logically conceivable and practically possible that they might be.

${ }^{13}$ N.E. Simmonds, Law as a Moral Idea (Oxford: Oxford University Press, 2007), pp. 34-36.
} 
As Raz acknowledged, at the heart of the concept of the rule of law is the idea that government is by laws rather than by caprice or unpredictable whim. ${ }^{14}$ In a lecture given in 2006, Tom Bingham, formerly Britain's senior Law, suggested that

'The core of the existing principle [of the rule of law] is ... that all persons and authorities within the state, whether public or private, should be bound by and entitled to the benefits of laws publicly and prospectively promulgated and publicly administered in the courts'. ${ }^{15}$

It is this idea which is captured in chapter 29 of the Magna Carta (as re-issued by Edward I in 1297) which is one of only three articles still in force in their original form: ${ }^{16}$

No freeman shall be taken or imprisoned, or be disseised of his freehold, or liberties, or free customs, or be outlawed, or exiled, or any other wise destroyed, nor will we not pass upon him, nor (condemn him,) but by lawful judgment of his peers, or by the law of the land. We will sell to no man, we will not deny or defer to any man either justice or right.

That article sets out an understanding of freedom in which to be free is to know that your life, liberty and possessions will not be taken away from you otherwise than in accordance with the law of the land. At the time the Magna Carta was enacted, to be declared an outlaw was to be deprived of those protections so that anyone could kill you with impunity.

Within legal philosophy, the concept of the rule of law comes in thin and thick versions. Fuller's account is a thin version, according to which a society is

\footnotetext{
${ }^{14}$ Rivers, 'The Living Rule of Law: an essay in virtue jurisprudence', Law \& Justice 174 (2015), pp.5-34 at p. 6.

${ }^{15}$ Bingham, 'The Rule of Law', Cambridge Law Journal 66 (2007), p. 69. He immediately qualified that statement by recognising that there are exceptions and qualifications to the principle that justice must be done in public, but contended that the force of the principle is such that 'any derogation calls for close consideration and clear justification.'

${ }^{16}$ The other two being chapter 1 (which relates to the liberties of the church), and chapter 9 (which relates to the liberties of London and other cities, towns and ports).
} 
governed by the rule of law when law is made according to the proper procedures and promulgated in the correct forms. This thin, formal version of the rule of law forms the basis for a thicker, substantive version of the rule of law in which law is presented in a more idealised fashion. We will return, later in our discussion, to consider why this thickening of the conception of the rule of law occurs so frequently.

Tom Bingham offers a recent example of the thick version of the rule of law. ${ }^{17}$ His eight principles for the rule of law are:

(1) The law must be accessible and so far as possible intelligible, clear and predictable;

(2) Questions of legal right and liability should ordinarily be resolved by application of the law not the exercise of discretion;

(3) The laws of the land should apply equally to all, save to the extent that objective differences justify differentiation;

(4) Ministers and public officers at all levels must exercise the powers conferred on them in good faith, fairly, for the purpose for which the powers were conferred, without exceeding the limits of such powers and not unreasonably;

(5) The law must afford adequate protection to fundamental human rights;

(6) Means must be provided for resolving, without prohibitive cost or inordinate delay, bona fide civil disputes which the parties themselves are unable to resolve;

(7) Adjudicative procedures provided by the state should be fair;

(8) The rule of law requires compliance by the state with its obligations in international law as in national law.

Whilst not quite offering a constitution or a bill of rights, Bingham's account of the rule of law contains a number of substantive values.

\section{The concept of the rule of law}

The modern lineage of the rule of law can be traced back to Thomas Paine's pronouncement in 1776 that 'in America THE LAW IS KING' ${ }^{18}$ and before that to Samuel Rutherford's 1644 political treatise Lex, Rex. The rise of political absolutism against which Rutherwood was reacting was a sixteenth and seventeenth century aberration. Before that, the rule of law had been a

\footnotetext{
${ }^{17}$ Tom Bingham, The Rule of Law (London: Penguin, 2011).

${ }^{18}$ Paine Common Sense (1776), (London: Penguin, 2004) p. 279.
} 
key idea of Christian natural law theory from Augustine to the High Middle Ages. The doctrine is perhaps most clearly expressed by John of Salisbury who, in the twelfth century, argued that 'Between a tyrant and a prince there is this single or chief difference, that the latter obeys the law and rules the people by its dictates, accounting himself as but their servant. ${ }^{19}$ Across nine centuries, John of Salisbury and Lord Bingham are united by their conviction that the rule of law is the idea that the law binds everyone within the realm, including the rulers.

\section{The rule of law distinguished from other societies}

The significance of the ways in which the law binds has been reflected on by the German legal theorist, Robert Alexy. His reflections have been provoked by a famous question posed by Augustine:

Remota itaque iustitia quid sunt regna nisi magna latrocinia? Quia et ipsa latrocinia quid sunt nisi parva regna? 'Justice being taken away, then, what are kingdoms but great robberies? For what are robberies themselves, but little kingdoms? 20

Augustine's question is intriguing. Because in The City of God he draws a resolute, though in my view ultimately wrong-headed, disjunction between law and justice, ${ }^{21}$ Augustine invites an enquiry into what makes a law a law if it is not justice. This enquiry can be undertaken by means of a thought experiment, though the consideration of a series of dystopias, or to be more precise, a series of dysnomias, of social orders which do not create law or in which the rule of law is defective.

\footnotetext{
${ }^{19}$ John of Salisbury, (1159) Policraticus. Tr. and ed. Cary Nederman (Cambridge: Cambridge University Press, 1991).

${ }^{20}$ Augustine, The City of God, Book IV, chapter 4.

${ }^{21}$ D.H. McIlroy, A Trinitarian Theology of Law: in conversation with Jürgen Moltmann, Oliver O’Donovan and Thomas Aquinas (Milton Keynes, Paternoster, 2009), pp. 191, 231232.
} 


\section{A. $\quad$ The senseless order}

Alexy first asks us to imagine a chaotic society which he calls the 'senseless order'. A 'senseless order' is a society in which those with power issue contradictory, impossible and arbitrary rules from moment to moment. Such 'a senseless order ... that neither reveals consistent purposes of the ruler ... nor makes a continuous pursuit of the subjects' purposes possible ${ }^{22}$ is obviously not one which is governed by law. In this state of affairs, those with power do whatever they want, without any logic or consistency to their actions. In the senseless order, it is impossible for subjects to exercise any real agency because their purposes are liable to be frustrated at any moment by an arbitrary, irrational or impossible command.

\section{B. $\quad$ The robber or slave state}

Now imagine that a new ruler comes to power in the senseless order. This new ruler has no more interest in the well-being of his subjects than his predecessor did. However, the new ruler observes that the arbitrary nature and unconstrained power of his predecessor's rule had made his subjects reluctant to plant crops, to start businesses, to form families or to make any long term plans, and therefore the state's economic development had been stunted.

The ruler therefore draws up a system of rules for the sole purpose of exploiting his subjects more efficiently. He issues rules which are binding on the subjects but which give them no rights whatsoever against the ruling elite. He makes no pretence whatsoever to be governing for the benefit of his subjects. The benefits of increased rationality and predictability which his rule delivers to his subjects are simply side-effects of the ruler's pursuit of his own interests.

In practice, such a ruler cannot rule alone. He will therefore, even if he is initially only concerned with achieving his own ends, find it necessary to cooperate with some others, and to have regard to the interests of his

${ }^{22}$ R. Alexy, 'On Necessary Relations between Law and Morality', Ratio Juris 2 (1989) p. 176. 
collaborators, even if his goals are evil. It is precisely this sort of arrangement that Augustine envisages in his band-of-robbers illustration. After posing his rhetorical question, Augustine continues:

'The band itself is made up of men; it is ruled by the authority of a prince, it is knit together by the pact of confederacy; the booty is divided by the law agreed on. If, by the admittance of abandoned men, this evil increases to such a degree that it holds places, fixes abodes, takes possession of cities, and subdues people, it assumes the more plainly the name of a kingdom, because the reality is now manifestly conferred on it, not by the removal of covetousness, but by the addition of impunity. ${ }^{23}$

The prince claims authority over the robbers and presents his rule as beneficial to the robbers. There is 'a pact of confederacy' in accordance with which 'the booty is divided by the law agreed on'. According to Augustine, social life, even amongst a band of robbers, requires the adoption of a rule with regard to the internal division of the booty. Augustine warns, however, that all this may be pursued at the expense of those who are not part of the band. The robber state therefore operates as a legal system for those it claims to benefit but it does not create law for those upon whom it preys.

The exposure to violence is central to the distinction between the members of the robber band and those upon whom they prey. For the members of the robber band, the pact of confederacy means that they are subject to a regime in which the imposition of sanctions is certain and the application of violence is controlled by the rules. However, those on whom the band preys are subject to a rule in which they are vulnerable to violence at any moment. On this reading, Augustine contends that the rule of law may apply for the benefit of some who are affected by the laws whilst at the same time amounting to nothing more than violence towards those who are only exploited by the laws.

${ }^{23}$ Augustine, City of God, book IV, chapter 4. 
Precisely this situation exists where there is a regime which permits chattelslavery. Chattel-slaves do not enjoy any protection against violence, they are not free to hold any property of their own, and they do not have any standing or legal personality of their own. Denied any protection against violence and any (share in) property rights, chattel slaves are neither subject to the rule of law nor under any moral obligation to obey the ruler's commands. For them, the regime is not a legal system it is a regime of unrestrained violence.

The chattel-slaves' plight is not just that they are the victims of unrestrained violence and that their property is insecure. Like outlaws, they are treated as objects not subjects. As the American legal philosopher John Rawls puts it:

'slaves are human beings who are not counted as sources of claims, not even claims based on social duties or obligations, for slaves are not counted as capable of having duties or obligations. Laws that prohibit the abuse and maltreatment of slaves are not founded on claims made by slaves on their own behalf, but on claims originating either from slaveholders, or from the general interests of society (which does not include the interests of slaves). Slaves are, so to speak, socially dead: they are not publicly recognized as persons at all. ${ }^{24}$

Robber and slave states are ruled over by elites. As between the sovereign and the other members of the elite, a legal system may exist. What the dysnomias of the senseless order and the robber or slave state reveal is that for the victims of such regimes to be exposed to unrestrained violence is to exist outside the rule of law.

\section{The managerial order}

Thus far in our thought experiment we have seen how the rule of law controls the incidence of violence. That is, however, only one half of the story. Fuller identified another form of social order where law is not essential: the managerial order such as a factory or a concentration camp.

\footnotetext{
${ }^{24}$ J. Rawls, 'Justice as Fairness: Political not Metaphysical', Philosophy \& Public Affairs 14 (1985), pp. 223-511 at p. 243.
} 
It is in the manager's interests to impose rules with which the subjects can comply, even if the manager is in charge of a concentration camp. The manager therefore has good reasons to comply with most of Fuller's eight principles of the rule of law. In the interests of efficiency, a manager will wish to issue directives which are communicated and which are 'reasonably clear, free from contradiction, possible of execution and not changed so often as to frustrate the efforts of the subordinate to act on them. ${ }^{25}$ The manager will not issue retrospective directives because 'no manager retaining a semblance of sanity would direct his subordinate today to do something on his behalf yesterday'. ${ }^{26}$ A manager may issue general rather than specific directives, but only if to do so is, in the particular case, more expedient.

The big difference between a managerial order and a legal system is that a manager has no obligation to follow the rules which he himself has set. Fuller argues that:

'the subordinate has no justification for complaint if, in a particular case, the superior directs him to depart from the procedures prescribed by some general order. This means, in turn, that in managerial relation there is no room for a formal principle demanding that the actions of the superior conform to the rules he has himself announced'. ${ }^{27}$

In a legal system, but not a managerial order, those with power are under an obligation to act in accordance with the rules. Fuller writes:

'Surely the very essence of the Rule of Law is that in acting upon the citizen (by putting him in jail, for example, or declaring invalid a deed under which he claims title to property) a government will faithfully apply rules previously declared as those to be followed by the citizen

\footnotetext{
${ }^{25}$ Fuller, The Morality of Law, p. 208.

${ }^{26}$ Fuller, The Morality of Law, p. 209.

${ }^{27}$ Fuller, The Morality of Law, pp. 208-9.
} 
and as being determinative of his rights and duties. If the Rule of Law does not mean this, it means nothing. ${ }^{28}$

It is the fact that the rules are understood as binding both on the subject and on the ruler which is the distinguishing mark of the legal system. This distinguishing feature has important consequences which go beyond giving the subjects a degree of protection against violence. In a managerial order, the only person whose purposes matter is the manager. In a legal system, the congruence between declared rules and official action means that its subjects are enabled to exercise their agency and to pursue their own purposes.

\section{The legal system}

The key distinctive of the rule of law is that the rulers count themselves as bound by the rules. This was one of the main themes of Terry Pratchett's writing. In a magazine interview, he said:

'The thing about law is that it must apply to the king as well as the subjects. Even if ultimately the rules don't apply to everybody, everybody must act as if they do and must obey them, whether their obedience is actually built in or they are choosing to obey them., ${ }^{29}$

Pratchett goes to absurd lengths to demonstrate that this is the case. In his Discworld novels, the great city of Ankh-Morpork, is ruled over by a benign dictator, the Patrician. The current Patrician, Lord Vetinari, educated at the Assassins' Guild School, has encouraged the self-regulation of crime. The Guild of Thieves regulates robberies and the Guild of Assassins murders. The Guild of Thieves keeps crime to a particular level, although they have generally found it easier to extract an annual payment from each wealthy citizen of Ankh-Morpork rather than go to the trouble of actually burgling or

\footnotetext{
${ }^{28}$ Fuller, The Morality of Law, pp. 209-10.

${ }^{29}$ Terry Pratchett, interviewed in Third Way (June 2003), p. 18. In Feet of Clay (London: Victor Gollancz, 1996) at pp. 106-7 Sergeant Vimes reflects that '[The Guilds] even maintained the law ... after a fashion. Thieving without a licence was punishable by death for the first offence. The Thieves' Guild saw to that. The arrangement sounded unreal, but it worked.'
} 
robbing them. ${ }^{30}$ With regard to murders, the Guild of Assassins will take care of any 'inhumation', subject to a fee. ${ }^{31}$ As for unauthorised attempts at robberies or murders, these are dealt with by the Guilds themselves. ${ }^{32}$

Pratchett is well aware that the regulation of robberies and murders is not the same as the delivery of substantive justice. In his novel Feet of Clay, Terry Pratchett has the Patrician explain that although people 'think they want good government and justice for all, ... what they really crave, deep in their hearts [is] [o]nly that things go on as normal and tomorrow is pretty much like today. ${ }^{33}$ The job of the agents of the law is not therefore to right all the wrongs in the world. It is the more limited task of ensuring that people are able to live with a degree of security and with a degree of freedom. ${ }^{34}$

Outside of fantasy literature, John of Salisbury's idea that the difference between lawful and unlawful rule is whether the ruler counts himself as bound by the law was picked up in the twentieth century by sociologist Georg Simmel $^{35}$ and re-introduced to legal philosophy by Fuller as the idea that

'there is a kind of reciprocity between government and citizen with respect to the observance of rules. Government says to the citizen in effect, "These are the rules we expect you to follow. If you follow them, you have our assurance that they are the rules that will be applied to your conduct." When this bond of reciprocity is finally and completely

\footnotetext{
${ }^{30}$ Pratchett, Men At Arms (London: Victor Gollancz, 1993), p. 13, 72.

${ }^{31}$ Pratchett, Pyramids (London: Corgi, 1990), pp. 43-44.

${ }^{32}$ Pratchett, Guards! Guards! (London: Corgi, 1990), pp. 44-46.

${ }^{33}$ Pratchett, Feet of Clay, p. 65.

${ }^{34}$ There is, of course, more than one way of assessing Pratchett's message about the proper role of the police force who are, in the persons of Captain Carrot and Sergeant Vimes, the guardians of the law. In a review of Night Watch, John Newsinger argues that the book has an anti-utopian message, about the importance of maintaining social order above all else, which marks an increasingly reactionary streak in Pratchett's work: 'The People's Republic of Treacle Mine Road Betrayed: Terry Pratchett's Night Watch' Vector 232 (Nov/Dec 2003) pp.15-16. Pratchett's rejection of utopia seems to have two roots. One is a cynicism about human nature, identified by Mendlesohn, 'Faith and Ethics', in Andrew M. Butler, Edward James and Farah Mendlesohn eds., Terry Pratchett: Guilty of Literature (Baltimore: Old Earth, $2^{\text {nd }}$ edn., 2004), p.160, and the other is a more specific wariness about 'authority figures and the corrupting influence of power': see Sue Thomason's review of Monstrous Regiment at p.29 in the same volume of Vector.

${ }^{35}$ G. Simmel, tr. Kurt H. Wolff, The Sociology of Georg Simmel, (The Free Press, 1950), p. 186.
} 
ruptured, nothing is left on which to ground the citizen's duty to observe the rules. ${ }^{36}$

To the extent that a state determines to govern in accordance with the rule of law, to that extent its rulers agree to circumscribe their freedom of action and commit themselves to not using force which has not been authorised by law. The rule of law binds, either because both rulers and subjects act voluntarily in accordance with the law or, when that fails, because there are effective mechanisms which enforce the law.

It is because the rule of law binds that it has the effects we identified in our thought experiment. First, the rule of law protects subjects from violence by identifying the circumstances when force may be used against them by the rulers and by other subjects. Second, the rule of law enables subjects to act as agents and to pursue their own purposes because they know how other subjects and the rulers are expected to behave. Rules, whatever their substantive justice or injustice, promote the good of stabilizing expectations. This enables people to make sense of their lives and to identify areas, however large or small, in which they may exercise their own moral agency. These two features of the rule of law are stabilised by a third feature, the establishment of law enforcement mechanisms which will punish unlawful violence and which will uphold subjects' expectations.

Law promotes our ability to pursue our own lives by outlining circumstances in which physical violence which interferes with our choices will not be tolerated, by specifying the legal consequences which will attend certain of our actions, and by identifying the behaviour of others on which we can reasonably rely when making our choices. Therefore, Kristen Rundle argues, the rule of law 'secures a certain quality of existence for those who live within it' ${ }^{37}$ This security may be compatible, as Hart pointed out, with many kinds of

\footnotetext{
${ }^{36}$ Fuller, The Morality of Law, pp. 39-40; see also Tom Bingham 'The Rule of Law' 66 Cambridge Law Journal (2007) p. 84.

${ }^{37} \mathrm{~K}$. Rundle, 'The Impossibility of an Exterminatory Legality: Law and the Holocaust', University of Toronto Law Journal 59 (2009), pp. 107-8.
} 
iniquity. ${ }^{38}$ Nonetheless, the legal system offers protection against unrestrained violence, both from itself and from others, in exchange for obedience to its rules.

The rule of law therefore exists to the extent that legal rules are applied and followed in practice. ${ }^{39}$ This means that societies can be governed by the rule of law to a greater or lesser extent, and the World Bank Institute has developed a set of tools for measuring this.

When the point is reached that citizens can no longer expect that others will follow the rules nor that others will be sanctioned if they fail to follow the rules, and can no longer expect that they will be protected from violence if they follow the rules, then the rule of law has collapsed. What is left is not enforcement of the law but rather acts of violence. It is a return to the Hobbesian state of nature in which officials simply have a comparative advantage in terms of violence. In a provocative and worrying book, Gary A. Haugen and Victor Boutros argue that this is the reality for half a billion people today. ${ }^{40}$ In many places around the world, significant progress towards the reduction of absolute poverty and outrageous inequality would be achieved if the poorest and most vulnerable were able to count on the protection which existing laws are supposed to offer them against violence, expropriation and other forms of coercion and exploitation.

\section{The rule of law as the reflection of God's law-like nature}

To be subject to the rule of law is to be subject to rulers who count themselves as bound by the rules, to enjoy the protection of knowing in what circumstances you may be subject to violence, and to have the space to exercise your agency and pursue your own purposes.

\footnotetext{
${ }^{38}$ Hart, The Concept of Law, p. 207.

${ }^{39}$ N. MacCormick, 'The Ethics of Legalism', Ratio Juris 2 (1989), p. 191.

${ }^{40}$ Gary A. Haugen and Victor Boutros, The Locust Effect: Why the End of Poverty requires the End of Violence (Oxford: Oxford University Press, 2014).
} 
This understanding of the rule of law ought to illuminate our understanding of what it is to be subject to God's law. The Christian God is, in God-self, lawlike. As Aquinas convincingly argues, God is, in a proper and unique sense, a law unto God-self. Aquinas names God's own law the eternal law.

For Aquinas, the doctrine of divine simplicity means that 'the end or telos of divine government is God himself, and his law is nothing other than himself' ${ }^{41}$ The telos of the universe is to be found in the subsistent goodness of God (ST I.103.2). Thus 'the eternal law which is nothing other than God himself, nothing other than the divine light in which the blessed see God' is the controlling category within which the natural law, Mosaic Law and the New Law of the Gospel are all only properly understood. ${ }^{42}$

The affirmation that God is a law unto God-self does not prevent God from doing new things in time but it does mean that God is reliable. One of the important features of the Christian understanding of God as impassible, and the one surely worth retaining (because it is intrinsic to the affirmation of God's aseity) even if the other aspects of the doctrine are discarded, is the affirmation that the Christian God is not like the Greek gods, that God is not capricious but faithful and constant.

Aquinas resolves any contradiction between God's law-like nature and God's freedom to act in time arguing that the eternal law is the law 'ordered by God for the governance of things foreknown by him', ${ }^{43}$ to be equated with God's providence, provided this is understood in the broadest terms as the entirety of God's good purposes for this world that He has created (ST I-II.91.1). God's rule is for the good of God's creatures and encompasses both God's 'conservation of things in the good and their motion toward the good., ${ }^{44}$

\footnotetext{
${ }^{41}$ F. Kerr, After Aquinas: Versions of Thomism (Oxford: Blackwell, 2002), p. 106.

${ }^{42}$ Kerr, After Aquinas, p. 106.

${ }^{43}$ Aquinas ST I-II, 91, 1 ad.1, see also 93; J.P. Torrell, tr. Robert Royal, Saint Thomas Aquinas Vol. II, Spiritual Master (Washington, DC: Catholic University of America Press, 2003), p. 283.

${ }^{44}$ Torrell, Aquinas Vol. II, p.235, italics in the original.
} 
At ST I-II.93.4-6, Aquinas presents his argument that God and the eternal law are identical in trinitarian terms. It is possible to say more about the eternal law than that it is the character and therefore ipso facto the purposes of the Father. Thus, at ST I-II.93.4 ad.2 he says 'the Son of God is not subject to the eternal law: but rather is himself the eternal law by a kind of appropriation' ${ }^{45}$ 'The eternal law embodies all that is true, just and good in relationship to God, that is, the law of love, and it is the Word himself who eternally embodies and so lives out this law. ${ }^{46}$ At q.93.6 ad.1, the Holy Spirit too is equated with, rather than regarded as subject to, the eternal law. ${ }^{47}$ It is the Spirit who leads created things to their appointed end. All of which suggests that a Christian doctrine of providence must be conceived in trinitarian terms - as overseen by the Father, ordered to the Son and accomplished in the Spirit.

The rule of law is reflected in the biblical presentation of the events of creation and redemption. The Genesis accounts of a rationally ordered creation rule out the possibility of conceiving of God's rule as a senseless order devoid of discernable purposes. I take it to be established beyond serious argument that Christian thinkers like William of Conches (1085c.1154) and Thomas Aquinas laid the foundations for modern science with their belief that a law-like God had created a world whose regularities could be observed. $^{48}$

The distinction between a slave state and a legal system throws the Exodus event into sharp relief. The Israelites were slaves in Egypt, without protection against violence (of which the population control methods with which the book of Exodus begins are a prime example) and exploited to serve Pharaoh's purposes. In contrast, the Old Testament resonates with the declaration 'YHWH Melek', the Lord is King. Israel's God is not a tyrant. God has

\footnotetext{
45 See also Aquinas, ST I-II.93.1 ad.2; 93.4. resp., ad.2.

${ }^{46}$ T. G. Weinandy, 'The Supremacy of Christ: Aquinas' Commentary on Hebrews' in Weinandy, Keating and Yocum eds., Aquinas on Scripture: An Introduction to his Biblical Commentaries (London: T\&T Clark, 2005), p. 228.

${ }^{47}$ See also Aquinas, Summa Contra Gentiles, IV, 20, n. 3572.

${ }^{48}$ James Hannam, God's Philosophers: How the Medieval World laid the foundations of Modern Science (London: Icon Books, 2009).
} 
given Israel a law and has bound God-self, through a covenant with God's people, to act faithfully and for their good.

What is more, the Bible consistently affirms that God's governance of human beings is not a managerial order in which God's laws are issued for God's benefit without regard for what is good for human beings. On the contrary, because God is good and because God is love, God's law is given through progressive revelation to enable human beings to discover their own good.

Aquinas's understanding of God as law-like is opposed by a theological position which insists on the primacy of God's freedom of action over the impossibility of God acting otherwise than in conformity with God's character. Richard Mouw has, however, argued that Reformed adherents to this position in fact end up at the same place in their understanding of God's relations to human beings because of the role which the idea of covenant plays in their thought. Thus, even in Reformed thought at its most voluntarist, 'a divine will that seems for all the world to be thoroughly arbitrary turns out to be bound by a commitment to lawful activity and covenantal fidelity'. ${ }^{49}$ Whereas for Aquinas, God is bound to act lawfully in se; for most Calvinists God has bound God-self by covenant to act lawfully.

One of the important features of the rule of law is the way in which it renders tolerable rule by fallible, even by bad human rulers. More than that, however, the rule of law reflects the character of God's rule of the universe. Christian theology should affirm that God is a law unto God-self, that God has bound God-self to humankind through covenants, that God has exercised God's rule over creation through the revelation of God's law through creation and the Scriptures, culminating in Jesus Christ who is both the Law and the law-giver in person. This understanding of God has, as its corollaries, an account of the space for human responsibility and free-will. It is because God is constant that human beings are freed to take responsible action in the world. Humans are not the helpless victims of fatum and fortuna. It is because God is law-

\footnotetext{
${ }^{49}$ Richard J. Mouw, The God Who Commands: A Study in Divine Command Ethics (Notre Dame, IN: University of Notre Dame Press, 1990) pp. 4, 100.
} 
like, that God has revealed to human beings what God requires and what will incur God's wrath.

Through the practices of law, human rule reflects divine rule by specifying the good, by protecting against evil, and by enabling personal agency, so that those who are subject to it are able to take their own initiative and to pursue their own goals within an ordered social framework in which good and evil are distinguished and violence is restrained. Rulers are called to imitate God's law-like character, not to ape God's majesty or to arrogate to themselves God's prerogatives.

\section{The relationship between the rule of law and justice}

I observed at the beginning of this paper that conceptions of the rule of law vary from thin, formal versions to thick, substantive versions. There is a noticeable tendency amongst contemporary legal theorists, including those who claim to be legal positivists, to move from a thin conception towards one which makes larger claims about the virtues of the rule of law.

The reason why this tendency is intrinsic to the concept of the rule of law is because the purpose of the rule of law is to bind rulers and subjects. Because it is difficult to devise adequate enforcement mechanisms which bind rulers effectively, the rule of law is more secure if the rulers act voluntarily in accordance with the rule of law. Because it is costly and inefficient to have to enforce the rules coercively, it is in the interests of rulers to secure their subjects' voluntary co-operation.

The robber state, even if its ruling class could discipline themselves to comply with the formal requirements of the rule of law, would still not have imposed law on their subjects because of their failure to give their subjects any moral, as opposed to prudential, reason for obedience. In order for a system of rules to generate a prima facie moral obligation of obedience, its rulers must at least pretend that the rules are just. Thus the rule of law exposes rulers to the critique that those claims are misplaced, hypocritical or just plain false. 
In order to secure voluntary obedience, it is in rulers' interests to give an account of why the rules are binding on their subjects. Thus Alexy argues, where a legal system exists, rulers claim that the rules are justified. ${ }^{50}$ MacCormick agrees that: 'Someone who openly claimed to rule only by brute power and without regard to any rational scheme of value could not be understood to be ruling through, far less under, law. ${ }^{51}$ The rulers claim that their rules are authoritative and should therefore be followed voluntarily by their subjects. ${ }^{52}$ The 'laws are intended to prescribe our conduct, and statements about legal rights and duties draw conclusions about what ought to be done, or what is justified, in the light of such prescriptions. ${ }^{, 53}$

I want now to discuss three implications of the proposition that the rule of law requires rulers to justify the rules, i.e. to give an account of why the rules are binding on their subjects.

First, because the rule of law enables us to identify the rules which govern a society, and places rulers under an imperative to claim that those rules are binding because they are just, the rule of law facilitates a conversation about whether the rules are in fact just. In a society governed by the rule of law, it is possible for the subjects to engage with the rulers in debate about the justice of the rules by which they are governed.

Second, the requirement to justify the rules supports the view that there are circumstances in which serious injustice is committed unlawfully. I do not mean to be sanguine about this: law, which uses force in the name of justice to restrain lawless violence, can and often has become the servant of injustice. Where, however, there is a commitment to law, it is the servant of unjust goals pursued by defined means and methods. It is at least an official statement of

\footnotetext{
${ }^{50}$ Fuller, The Morality of Law, pp. 209-10.

${ }^{51}$ MacCormick, 'Natural Law and the Separation of Law and Morals', in R.P. George ed. Natural Law Theory: Contemporary Essays (Oxford: Oxford University Press, 1992) pp. 105133 at p. 120.

${ }^{52}$ Rivers, 'The Living Rule of Law', p.14.

${ }^{53}$ Simmonds, Law as a Moral Idea, p. 119.
} 
the circumstances in which violence and injustice will occur. There is a moral gain, however slight, in the making of such a statement.

Graver dangers come because of the capacity of societies to regard certain categories of people as objects rather than subjects and to exclude them from the protection of the rule of law. Thus, the institution of chattel-slavery is built upon brute power. Similarly, the destruction of the Jews after Kristallnacht was achieved by treating them as non-persons, as objects, not entitled to any protection from violence. ${ }^{54}$ As Martin Chalmers chillingly puts it, from Kristallnacht on, 'Jews realize[d] that there is no one and nothing to protect them. ${ }^{, 55}$

Third, it explains why Christian natural law theory gave the answer it did to the question: if a law is not binding, is it a law at all? For Christian natural law theory, the rule of law is not just a thin conception of using the proper procedure and forms to change the law. The rule of law is also the thick conception of adopting rules which are lawful, i.e. which are sufficiently justified to be binding on the conscience of those who are subject to them. The rule of law is about a certain quality of rule. Christian natural law theory understood political rule as having been given for the protection and development of the common good, and as subject to the divine rule-making of God in nature and in Scripture.

Augustine, in his early dialogue On Free Choice of the Will, had made one of his protagonists say: Nam lex mihi esse non videtur, quae iusta non fuerit ("For a law that was not just would not seem to me to be a law"). ${ }^{56}$ Aquinas cited Augustine's dictum in the Summa Theologiae I-II. Q.95 arts 2 and 4, in preparation for his discussion in Q.96 art. 4 of the question, "Whether Human Law Binds a Man in Conscience?"

\footnotetext{
${ }^{54}$ K. Rundle, 'The Impossibility of an Exterminatory Legality', p. 65-125.

${ }^{55}$ M. Chalmers 'Preface to Victor Klemperer, I Will Bear Witness: A Diary of the Nazi Years 1933-1941.' Tr. Martin Chalmers. (New York: Random House, 1998), p. xiv.

${ }^{56}$ There is an obvious tension between this dictum and Augustine's later position that human justice was so far removed from divine justice that it was not worthy to be called by the same name.
} 
For Aquinas, a ruler who rules solely in his own interest (Aquinas ST IIII.42.2 ad.3) as King John did, was a tyrant even if his laws met all the formal requirements. ${ }^{57} \mathrm{~A}$ rule which had been adopted according to the correct procedure and which was in the proper form was nonetheless unlawful if was so unjust that it fell outside the scope of the authority which the ruler had under God.

Understood in this way, Christian natural law theory claims that law, though and precisely because it binds, should protect against violence, enable agency and invite voluntary obedience. Laws make effective agency possible by contributing to the structure, to the framework, within which individual decision-making is made possible and given meaning. ${ }^{58}$ Laws make social relationships between what Fuller calls 'friendly strangers' ${ }^{59}$ possible by establishing basic expectations which people can have of one another. By so doing, rules also create areas of meaningful freedom in which people are able to plan and act because they know what they can expect from others and what is expected of them.

By focussing on whether laws bind in conscience, Christian natural law theory critiques laws which are unjust as defective examples of the species. It draws our attention away from the question which we have considered today: what does it mean to say something is lawful?, towards the deeper question: is the action just?

\section{Conclusions}

A sober acknowledgement of the limits of law is inherent to Christianity's DNA. A major burden of my work as a theologian of law has been to argue that Christianity puts law firmly in its place. The doctors of the Church, Paul, Augustine and Aquinas all teach that law, even divinely given law, is not

\footnotetext{
${ }^{57}$ King John's rule showed 'little regard for due process, custom or basic principles of fairness': Andrew, The Church and the Charter, pp. 13-14.

${ }^{58}$ O'Donovan, The Ways of Judgment, (Grand Rapids: Eerdmans, 2005), p. 68.

${ }^{59}$ Fuller, 'Human Interaction and the Law', American Journal of Jurisprudence 14 (1969) pp. 1-36 at p. 27.
} 
sufficient to deliver justice. ${ }^{60}$ Our inability to follow God's law, to live lawfully, ${ }^{61}$ exposes our need for a Saviour and our dependence on the Holy Spirit.

Nonetheless, Christian natural law theory has affirmed the rule of law as more than an a-moral instrument of governance without concluding that it is a guarantee of substantive justice. The rule of law is a limit on power because it requires rulers to comply with formal requirements which give subjects warning of when violence will be used against them. This commitment to rules creates space in which subjects can act as effective agents. The imperative to secure as much voluntary obedience to the rules as possible leads rulers to offer justifications of why the rules are binding and this makes possible a critique and debate about whether the rules are in fact just.

The early legal positivists, John Austin and Hans Kelsen presented a distorted understanding of law as intrinsically coercive, mistaking force as the substance of law rather than an accident of it. H.L.A. Hart rightly rejected that account ${ }^{62}$ but wrongly insisted that the Nazi regime was guilty of enacting bad laws and not also of a serious degradation of the rule of law without which some of its worst excesses may not have been possible. ${ }^{63}$

As befits the occasion, I have made an academic case for the relative, but indispensable, importance of the rule of law for the good governance and prospering of human societies. Haugen and Boutros in The Locust Effect make a far more effective plea for the urgent need to make every endeavour to

\footnotetext{
${ }^{60}$ McIlroy, A Biblical View of Law and Justice (Carlisle: Paternoster, 2003); A Trinitarian Theology of Law.

${ }^{61}$ McIlroy, 'The Law of Love' Cambridge Papers 17(2) (2008); Rivers, 'The Living Rule of Law'.

${ }^{62}$ H.L.A. Hart, The Concept of Law, pp. 20-25.

${ }^{63}$ H.L.A. Hart, 'Positivism and the Separation of Law and Morals', Harvard Law Review 71 (1958), p.593; K. Rundle, in Forms Liberate: Reclaiming the Jurisprudence of Lon L. Fuller (Oxford: Hart, 2012), pp. 66-78, points out how Gustav Radbruch moved from a legal positivist position before World War II to a natural law position because of his assessment that 'the positivist insistence on the separation of law and morality had powerfully contributed to the horrors of the era and especially to the failure of the German legal profession "to protest against the enormities which they were required to perpetrate in the name of law"., at p.66.
} 
deliver the benefits of the rule of the law to half a billion of the poorest and most vulnerable people on our planet.

Their plea is supported by data from the World Bank Institute which shows that an improvement of one standard deviation in the rule of law produces a three-fold increase in incomes and a two-thirds reduction in infant mortality. That is the gap between respectively Somalia and Cote d'Ivoire, Cote d'Ivoire and El Salvador, El Salvador and Italy, and Italy and the United Kingdom. ${ }^{64}$

In his recent work, Justice in Love, Nicholas Wolterstorff argues that love and justice are necessarily not incompatible. ${ }^{65}$ Rightly understood, justice has its place within love. Love he defines in terms of care: to love someone is to promote the goods in her life as an end in itself. Glossing Wolterstorff, might we venture to say that the rule of law serves the ends of love by protecting subjects against violence and by enabling them to pursue goods as responsible agents.

I think all this can be said without denying for one moment that law has been used as a force of oppression throughout history, that people have been treated as objects not subjects by legal systems which have in effect denied their humanity, that the poor have been denied the protection in practice that the law offered them in theory. Indeed, I would go further and claim that it is a belief in a God of justice, who is law-like in nature, which provides the strongest resources for a critique of the injustices committed both within and without law. Moreover, knowing that we are accountable to such a God gives us the clearest incentive to regard ourselves as bound by what is morally right, whether or not there is a law against an unjust action and whether or not any such law is likely to be enforced against us.

\footnotetext{
${ }^{64} \mathrm{http}$ ///info.worldbank.org/governance/wgi/index.asp, accessed on 28 August 2015. One of my worries is that the recent cuts in legal aid leave many people unable to access a lawyer to vindicate their rights. Such people are then dependent on voluntary obedience to the rule of law by the powerful. I fear that unless the cuts are reversed or alternative agencies act on behalf of these people, even within the UK we may see significant numbers of people deprived of the benefit of the rule of law: see further Andrew Caplen and David Mcllroy, Speaking Up: Defending and Delivering Access to Justice (London: Theos, 2015).

${ }^{65}$ N. Wolterstorff, Justice in Love, (Grand Rapids: Eerdmans, 2011).
} 
David McIlroy is a practising barrister, and Visiting Senior Lecturer in Law at SOAS, University of London as well as Associate Tutor in the Mission of Justice and the Theology of Law at Spurgeon's College 